\title{
The Brazilian nursing workforce faced with the international trends: an analysis in the International Year of Nursing
}

\author{
I ${ }^{1}$ Helton Saragor de Souza, ${ }^{2}$ Carla Andrea Trapé, ${ }^{3}$ Celia Maria Sivalli Campos, \\ ${ }^{4}$ Cassia Baldini Soares I
}

Abstract: The article analyzes the condition of the Brazilian Nursing workforce when confronted with international trends. Diagnoses in publications by international organizations marked the confrontation of international trends with the reality of Brazilian Nursing, based on secondary research data. The analysis allows asserting that the Brazilian Nursing workforce follows international trends, essentially, because the social and sexual division of work and the foundations of the origin of Nursing as a capitalist occupation are maintained. At the same time, the historical-structural assumption of female proletarianization is based on the following: the disparities between men and women in pay and access to prominent positions in the market; combined inequalities across nations and regions in the supply of the labor market, which stimulates immigration of professionals; exploitation of older professionals, in the context of restricted access to retirement and labor rights; and exposure to violence and harassment, associated with the potential for overload and work intensification, which result in workers contracting diseases. In summary, it is observed that the pillars of female proletarianization and professionalization of Nursing remain in today's differentiated forms of workforce exploitation, being configured depending on the intersections of gender, racial-ethnicity, and regional-nationality.

> Keywords: working conditions; nursing; labor force; working women; health services.

\author{
${ }^{1}$ Instituto de Saúde e Sociedade, \\ Universidade Federal de São \\ Paulo. Santos-SP, Brazil (hs. \\ souza@unifesp.br). \\ ORCID: 0000-0002-3074-6386 \\ 2 Escola de Enfermagem, \\ Universidade de São Paulo. São \\ Paulo-SP, Brazil (carlaens@usp.br) \\ ORCID: 0000-0002-3272-6565 \\ ${ }^{3}$ Escola de Enfermagem, \\ Universidade de São Paulo. São \\ Paulo-SP, Brazil (celiasiv@usp.br). \\ ORCID: 0000-0002-1149-9025 \\ ${ }^{4}$ Escola de Enfermagem, \\ Universidade de São Paulo. São \\ Paulo-SP, Brazil (cassiaso@usp.br). \\ ORCID: 0000-0002-8457-3775
}

Received: 20/07/2020

Approved: 07/12/2020

Revised: 20/03/2021 


\section{Introduction}

The work of health occupations was taken as a study object by founding authors of Brazilian collective health (DONNANGELO, 1976; AROUCA, 2003), initially with analyses that focused on the medical practice, since the departments of origin of these researchers were in medical schools. Analyses concerning the workforce and human resources in health gradually merged over time, even though they were in different fields (NOGUEIRA, 1983).

Historically, studies on the Nursing work in Brazil have focused mainly on the issues of the capitalist social division in health and the manifestations of the forms of work organization in the professional routine. The analysis of the work processes of the Nursing categories, inserted in the collective work in health, represents a significant part of the production in this area, which blends elements of the sociology of work and of professions, developed in the 1980s and 1990s (MELO, 1986). The quantitative progression of scientific production, however, does not do justice to the weight that Nursing has in the work of health occupations, as demonstrated by the data, which point to the presence of more than 1.8 million professionals ${ }^{1}$, making up more than $50 \%$ of the health workforce in Brazil (MACHADO, 2017).

Foucault (2002) considers that the advent of modernity established rationality and discipline for hospital reorganization. In the historiography of the institutionalization of Nursing, English pioneering is associated with wars in which men fought and women cared for people; however, the core of the social division of work cannot be reduced to the military "campaignist" logic. The capitalist constitution of Nursing, that is, the transition from charitable, religious, or vocational activity to professional occupation, occurred in the context of the Industrial Revolution. In this process, modern Nursing became a reality, with the establishment of rational and disciplinary methods of hospital routines (ORNELLAS, 1998).

In this way, the professionalization of Nursing developed subjected to the process of conformation of the workforce and employment in the central capitalist countries in the $19^{\text {th }}$ century, a historical process called proletarianization, which affected men, women, and children in the factories. State and capital have violently intervened in the historical conformation of workforce, imposing structural measures, such as expropriation of direct owners, separation of producers and their means, suppression of the subsistence means, except through the sale of their workforce (expulsion 
from the land, the classic enclosures in England), and work fragmentation and mechanization, with its consequences on the disqualification of the worker, as well as the conversion of the workers' means of living into capital.

Industrial proletarianization: the work means and the productive dimension of social life became means of production and of subordination of work and human needs to the appreciation of capital (MARX, 2013). This historical development constituted the contingent of urban workers with terrible living conditions, high child mortality, and even the struggle for civil, labor and social rights, which resulted in the expansion of health care.

The capitalist social division of work in health and the contemporary conformation of its occupations in a period similar to the industrial proletarianization expressed itself in the development of the technical dimension and of the professional specializations, as manifestations of the capitalist sociability. The insertions in the workplace were differentiated even within the same profession, with the medical professional, for example, going from being an autonomous liberal professional to being a component of the State's staff (FREIDSON, 2009). It is noted that the division of work in capitalism does not refer primarily and exclusively to the technical dimension, but to the reproduction of the social class structure through the social division of work, since technique is appropriated differently in the reproduction of class differences. Thus, in health, with the complexification of the medical work, from the constitution of the modern hospital, the control of the intellectual dimension became the physician's responsibility and the infrastructural and manual elements were left to other workers, which gave rise to Nursing, which in turn is fragmented among workers more and less skilled in performing control and manual tasks (MENDES-GONÇALVES, 2017).

It is worth noting that the profession of the physician was also sanctioned by the State, which gave the profession centrality over other health care occupations. In the constitution of Nursing, the division between ladies and nurses represented the intellectual-manual division and showed the distinct insertion of class fractions in Nursing, women from popular social backgrounds inserted themselves into performing tasks meant for the nurses. In the general context of proletarianization, women workers were already marginalized to less skilled occupations in the transition from handicraft manufacturing to large industry (SAFFIOTI, 1982), the capitalist sexual division of work in health also marked such distinctions, with the insertion of women especially in manual practices. 
Undoubtedly, technical rationalization, supported by scientific and administrative knowledge in Nursing, has promoted unquestionable developments in health care. However, contradictorily to the human action of care, developed within personal, family or traditional relationships, care actions become a capitalist activity of social reproduction (SOUZA; MENDONÇA, 2017).

The expansion of the health services by the public systems and the private entrepreneurship around the world in the $20^{\text {th }}$ century, together with the strong feminization of the occupation, enabled the proletarianization process of women in the $19^{\text {th }}$ and $20^{\text {th }}$ centuries, in the center and periphery of capitalism. In other words, Nursing was one of the occupations that led to the insertion of women in the labor market. However, the cultural relationships between the genders in each reality and the different forms of production policies of the capital accumulation regimes and their respective national states, as well as the provision of health care systems, have forged specific and concrete situations.

The female conformation of the Nursing occupation in Brazil has a unique trajectory, coherent with the characteristics of women's work in Brazilian society, whose historical configuration was associated with the female role in the general proletarianization process. Women were the majority labor force in the textile industry between the late $19^{\text {th }}$ and early $20^{\text {th }}$ centuries, with a minority presence in the other sectors. In the $20^{\text {th }}$ century, the service sector developed, with heterogeneous activities, a sector in which the Nursing category is inserted. Women started to be predominantly occupied these positions, mainly because they were "expelled" from industrial activity (SAFFIOTI, 1982).

The growth of the service sector of the economy was a milestone in the post-World War II period for the countries of the Organisation for Economic Cooperation and Development (OECD). The share of services in total employment went from $24 \%$ in the 1950 s to $57 \%$ in 1996 . The progression of jobs in this sector, in the same period, went from 17.5 million to 59.8 million, representing a $342 \%$ increase (GADREY, 2001).

The Brazilian reality presented peculiarities in the growth pace of employment in the services sector in the second half of the $20^{\text {th }}$ century, with lower levels in relation to those of the developed capitalist countries, although with a growing tendency to considerable expansion in the last two decades. Regarding the health services, the 
institutionalization process of the Unified Health System has created thousands of public job openings and encouraged the growth of jobs in the private sector.

From the theoretical considerations about the Nursing workforce, the various implications of how women workers experience their daily work and, consequently, how this work impacts on their way of life, it is practically impossible to disregard that the Nursing workforce materializes the intersections of age, race/skin color and gender, among others, in the conceptual representation of the class diagonal (BENSAID, 1997), a conceptualization that refers to the understanding that class insertion is the expression of the set of social relations of the individual's experience, beyond the consideration of only employment and occupation insertion. In this way, the insertion of working women is different from that of working men, just as there are inequalities between black-skinned workers in relation to white-skinned workers. Race/Skin color and gender relations combine with the general elements of capitalist sociability and work exploitation. The discussion of empowerment/ disempowerment in work and living conditions requires various syntheses or, as Hirata and Kergoat (2007) assert, it requires "the interrelation of multiple divisions of socially produced work".

Starting from the gap left by the absence of debate in scientific productions about the workforce, mainly due to the naturalization of capitalist exploitation in the neoliberal context, which does not seem to make its recognition and naming necessary (BARBOSA, 2010), the objective of this article is to analyze the Brazilian Nursing workforce in the face of the international trends, anchored in the Marxist framework and in the discussion about the relationship between the organization of the capitalist mode of production and capitalist work relations in health care.

\section{Method}

To achieve the study objective, secondary data (JOHNSTON, 2017) of socioeconomic identification, labor market and working conditions of nurses, and nursing technicians and assistants working in Brazil were taken as a reference, presented in the Brazilian Nursing Profile Survey (MACHADO, 2017), which collected data from Nursing professionals in $50 \%$ of the Brazilian municipalities, in all states of the federation. The analysis was conducted by checking against contemporary global data on the Nursing workforce available in the following 
reports and productions: 1) from the WHO, about the state of Nursing in the world (WHO, 2020); 2) from the WHO, about gender equality of the health workforce (BONIOL et al., 2019); 3) from the WHO, about health employment in relation to the countries' economic growth (BUCHAN; DHILLON; CAMPBELL, 2017); and 4) from the International Labor Office (ILO, 2017), about improving employment and working conditions in the health services.

The research studies, both national and international, were developed in similar periods. In this paper, it was sought to analyze points where the international trends relate to the main elements of the current insertion of the Nursing workforce in the national and international scenario.

\section{Results and Discussion}

Based on research data from the World Health Organization (WHO) on gender equality, as well as of the International Labor Organization (ILO), in a universe of 234 million workers in 104 countries, the results of the study by BONIOL et al. (2019) signaled that female employment accounts for $70.3 \%$ in the health services and in the social sector. Across all the activities, the proportion of female employment is $39.5 \%$ (ILO, 2017).

With reference to gender distribution in Nursing, the WHO shows a $90 \%$ composition of women, with an incipient female presence in relevant management positions, both in the health services and in state policy (BUCHAN; DHILLON; CAMPBELL, 2017). It is worth remembering that the Nursing categories represent $69 \%$ of the health care workers and that the professionals that make up the Nursing categories total 28 million worldwide (WHO, 2020). Nursing in Brazil follows the same trend, being composed mostly of female workers, who represent $85.1 \%$ of the total category (MACHADO, 2017).

The predominant feminization of the Nursing occupations, both in Brazil and in the world, brings to light two essential categories to understand the situation of the Nursing occupations, the social division gender divisions of work, categories that concretely denote inequalities, both with regard to the unequal distribution between the genders in labor market occupations, and the inequality in the division of domestic work, an inequality similar to that described in a broad analysis of women's work (HIRATA; KERGOAT, 2008). 
The combination of unequal work contracts with the unequal division of care and domestic work is the main element of the international trend in the Nursing workforce.

This global social relationship engenders the second or third working day for the health care workers (BONIOL et al., 2019); and also, on the working woman who assumes the greatest responsibility for child care. A report addressing working conditions and employment in health services (ILO, 2017) identifies the difficulty for female health workers to manage childcare time and work activities, often leading to the choice of part-time work and absenteeism. The report described data on nurse absenteeism in South Africa, identifying an increase in absences during children's school holidays.

These conditions, identified in jobs with formal work contracts, are aggravated if we consider that women, especially those with low incomes and with informal work contracts, are assigned the health care of family members (BONIOL et al., 2019). In Brazil, there is special fluidity in the boundary between the professional work of home caregivers and professionalized domestic work (GUIMARAES; HIRATA, 2008). Although most female nurses do not have professional insertion as caregivers, domestic care and space are historically attributed to women.

The second component of the international trend refers to the pay gap between genders, occupations, and countries. The increase in health sector jobs and the share of this sector of the economy in the overall national accounts in the global scenario have not been accompanied by a proportional increase in the workers' earnings. The intrinsic expansive dynamics of capitalism is observed in this process, in the expansion of the number of workers and in the transposition of the frontiers of appreciation. In an unequal and combined manner, salaries are disproportionate across the different professional categories and countries, following the characteristic concentration of capitalism, whereby in countries with central capitalism and considering workers coming from more stable social classes, salaries are better.

This statement is confirmed by the results of an analysis of some health occupations (physicians, nurses and obstetricians, and caregivers) in twenty countries. The mean salaries are higher in Germany, Sweden, the Netherlands, the United Kingdom, and the United States, while the lowest mean salaries are in countries like Russia, Ukraine, the Czech Republic, Brazil, India, and Poland. In addition to this inequality, the salary disparities between the three occupations are 
greater in this second group; the highest salaries are reserved for physicians and the lowest for caregivers (TIJDENS; VRIES, 2011). Even in central capitalist countries, nurses' salaries are not among the highest mean salaries for health care workers (TIJDENS; VRIES, 2011). Despite their majority in the health and social sectors, women are more subjected to unstable part-time employment, have lower mean salaries and are paid, on average, salaries $11 \%$ lower than those of male workers (ILO, 2017). In Nursing, the disparity widens to nearly 28\% lower salaries for women when compared to men's (WHO, 2020).

In the publications of the World Health Organization, the situation of salary and job disparity between women and men is highlighted. The publications advocate the need for public policies by the national States against gender discrimination that review restrictive social norms assigned to women in public life; safety restrictions on mobility; legal rights and unequal access to formal education (BUCHAN; DHILLON; CAMPBELL, 2017). The WHO publications also note the worldwide problem of underfunding of investments in human resources for health, which results in low salaries for broad sectors of nursing and health services in general (BUCHAN; DHILLON; CAMPBELL, 2017). It is advocated that national states should have a salary policy to maintain these professionals, even to avoid the exodus of health workers to rich countries. However, although it is recognized that public policies that have a positive impact on the insertion of women in the labor market and on their lives are necessary and should be the focus of pressure from social movements, it is advocated that they should not be limited to adjustments in the disparities for the insertion of women in a competitive society, on a similar level of equality, according to liberalism principles.

The proletarianization of women reveals a social relationship established by capital in its global dimension of a higher level of exploitation among women. Women's inequality in the labor market in capitalist societies does not harm them exclusively, it also causes damage to their families and to the places where they live, given the greater role that women play in family income in Brazil and in the world. It is no mere coincidence that, in the 2000-2017 period, the economic activity of the health services had higher growth than the mean of the other activities (WHO, 2019) and, consequently, the revenue of the economic agents, especially financial. This process has been sustained in correlation with the increase in jobs, mostly for women. Therefore, it is fundamental to interpret work as a favorable space for the appreciation of capital. 
The issue of salary gap in the Brazilian reality is also expressed in the composition of the Nursing workforce, since only $23 \%$ of the workers are nurses and $77 \%$ are nursing technicians and assistants (MACHADO, 2017). The division of work into categories results in lower salaries and a greater repetitive workload for the categories of workers in more unstable reproduction conditions, as well as those of nursing assistants and technicians; therefore, it results in different wear out levels, related to the workload and to the type of work; it is not uncommon for Nursing professionals to have more than one job to make up their monthly income. Among the graduates, $33.5 \%$ report more than one activity, while $26 \%$ of the technicians and assistants describe the same situation (MACHADO, 2017).

International publications address salary disparities, however, when exclusively considering the salaries, they disregard the set of incomes; a more adequate approach would be one that considers the set of benefits and rights, material support (BURAWOY, 1990), referring to the material conditions of subsistence for reproduction of the workforce. Access to labor and social security rights is also related to the reality of the workforce, especially regarding the age group composition of the professionals. In the Brazilian case, the restriction of these rights implies spoliation of older segments of workers close to retirement.

Globally, the Nursing workforce is young, with $38 \%$ of the workers under the age of 35 and only $17 \%$ over the age of 55 (WHO, 2020). In Brazil, $77.6 \%$ of the nurses and $75.1 \%$ of the assistants and technicians are in age groups below 46 years old (MACHADO, 2017).

In the Americas and Europe, on the other hand, the Nursing workforce is characterized by having higher percentages in older age groups; this percentage does not consider disparities across the countries of these continents (WHO, 2020). There are regions with a higher percentage of the Nursing workforce over the age of 55, presumably near retirement, and a relatively small contingent of young professionals. In Australia, in 2015, there were $40 \%$ of Nursing workers and midwives aged 50 years old or older, while in the United States that same year, there were $50 \%$ of registered nurses belonging to this same age group (ILO, 2017).

The aging trend of the Nursing workforce observed in high-income countries is not confirmed in the Brazilian reality data; however, the contingent of older workers is substantively impacted by changes in the labor laws and by the restriction imposed by the dismantling of social security, both situations being detrimental 
for the workers, especially among the low-salaried. It is known that $80 \%$ of the retired workers receive up to 2 minimum wages from social security, which results in increased exploitation of workers, forcing them to work longer and accept more precarious working conditions, in the form of pretended solutions, but which are proposals of the capitalist system in crisis (GENTIL, 2019). The consequence is the increased exploitation of a contingent of older workers in the health sector, especially those with lower salaries, as is the case of a significant portion of the Nursing categories. The salary inequalities associated with the growing restriction of work-related rights and social security can be configured as an additional element of spoliation of the workers in the sector.

The third element highlighted in the international trend is the unequal and combined dynamics of disparities across countries and regions, with the incorporation of the immigrant workforce in the central capitalist countries.

Migration flows are influenced by the unequal socioeconomic conditions across countries, regions of the same country, and territories within the same region. The evasion of professionals from their places of origin is related to the low economic development of countries and regions, in search of improved living conditions and professional development. Nurses migrate or emigrate choosing places with favorable language conditions and the possibility of equivalence in level of training and education (BUCHAN, 2007).

In the period from 2011 to 2016, immigration patterns were established from peripheral countries to rich countries, which put on their agenda the need to incorporate foreign professionals for the coming years (United Kingdom, Japan and Germany, among others). Similarly, there are relationships of flows of professionals by regions, for example, immigration into South American countries (RODRIGUES; ANGELICA-MUNOZ; HOGA, 2019).

The global trend of concentration in large centers and shortage in certain continents is corroborated by the displacement of professionals from poorer countries to richer countries, in search of higher salaries. The world's largest concentration of nurses, approximately $81 \%$, is found in the Americas, Europe, and the Pacific regions, continents that, together, account for $51 \%$ of the world's population. Countries with a lower percentage of nurses are in Africa, Southeast Asia, Mediterranean regions, and parts of Latin America. Low-income countries have a low density of nurses, 9.1 
nurses per 10,000 inhabitants, compared to 107.7 per 10,000 inhabitants in highincome countries (WHO, 2020).

While publications on the health and nursing workforce address immigration as a way for skilled labor to seek better salaries, it also notes that immigrant nurses are more subjected to worse working conditions. These immigrant nurses, in addition to worse working conditions, were also more exposed to risks of violence, associated with discrimination generated by racial-ethnic aspects (SCHILGEN; NIENHAUS; HANDTKE; SCHULZ; MOSKO, 2017). The literature shows considerations on the incorporation of these women workers into jobs with worse working conditions and salaries in relation to the group of workers in similar job positions (HONGYAN; WENBO; JUNXIN, 2014). It is worth noting that, in the international Nursing publications, the approach focuses on graduate professionals, with little attention paid to non-graduate professionals (WHO, 2020).

The global trend of concentration in large centers and scarcity in certain continents is caused by the displacement of professionals from poorer countries to richer ones, in search of higher salaries. In Brazil, the combination of concentration and shortage of professionals across the Brazilian regions and states also occurs, although without a defined diagnosis of "flee" of professionals.

In an analysis of international migration flows of nurses, the WHO signaled that, although they have been produced, data on migration and mobility are still insufficient to assess the complexity of the migration movements. An analysis of data from 86 countries showed that $13 \%$ were born or trained in other countries, that is, one out of eight nurses. In high-income countries, some dependence on foreign nurses was reported for work in health, since the percentage of nurses born or trained in other countries was 15.2\% (WHO, 2020).

In Brazil, the combination of concentration and shortage of professionals across the Brazilian regions and states also occurs, although without a defined diagnosis of "flee" of professionals. The findings by SILVA et al. (2016) prevalently indicate three migration flows of nurses, two national and one international. One of them is the national migration guided by the search for professional education, with a high rate of migration to states in the Southeast, which concentrate vacancies in undergraduate and graduate courses. Another motivation for national migration is the search for job opportunities, to regions with a concentration of wealth and job offers; and a third 
flow is that of international migration, mainly of return migrants, usually older, married workers, who return to their country of origin for family reasons.

In Brazil, 49\% of the Nursing workers hold jobs in states in the Southeast region (MACHADO, 2017). Consistent with this concentration, these regions also concentrate the highest percentage of higher education institutions, especially private, which have shown a disorderly increase in recent years. The SouthSoutheast axis of the country concentrates $71.2 \%$ of the undergraduate Nursing courses (TEIXEIRA et al., 2013).

In addition, the progressive precariousness of the work contracts in the public sector and the weak regulation of the labor market in the Brazilian health sector reinforce the regional inequalities in the distribution of health professionals (CRAVEIRO et al., 2015). As the health services are governed by the same market logics, the distribution of the health workforce is unequal and follows the movement of the market, which concentrates service delivery and training companies in regions of higher income concentration, relegating other regions to the deficit of health workers. In terms of Nursing in Brazil, there is a trend for the persistence of the training pattern characterized by the concentration of excellence institutions in the urban centers of the most developed axis of the country, alongside many institutions that do not meet the qualification standards for teaching and that do not develop research and extension. At the same time, the trend on the horizon is a reduction in the number of graduates in the coming years and the saturation of the private work force (DAL POZ; VARELLA; SANTOS, 2015).

In the proletarianization process, the incorporation of foreign workforce to lower the costs for capital can be observed, as was the case with the incorporation of Scots and Irish in England during the Industrial Revolution (ENGELS, 2008). Historically, the periods of capital accumulation counted on the massive presence of immigrant workers to make up the relative overpopulation in the central capitalist countries.

In Brazil, in face of the reality of proletarianization in the $20^{\text {th }}$ century, the segment of workers integrated into the urban market was in a better condition than the mass of the dispossessed, which lived at levels below the possibility of subsistence. The constitution of the urban labor force in the 1950-1960s was based on rural migrants, who made up the relative overpopulation for yet another accumulation cycle.

Regarding the national Nursing workforce, a significant portion of these workers comes from impoverished sectors, with unstable conditions resulting from informality 
in their previous professional history (SOUZA; MENDES; CHAVES, 2019). In the research study on the Nursing profile in Brazil, data on the education of the worker's mother, or the significant person who replaced her, it was identified that $64 \%$ had elementary schooling level, which means having 4 to 8 years of formal education. It is noteworthy that $46.6 \%$ of the Nursing professionals had a close relative who worked in the profession, configuring a "Nursing lineage" (MACHADO, 2017).

The fourth element of the international trend deals with the working conditions, and with work intensification and overload, their consequences on workers' health, and exposure to violence. The publications of the multilateral organizations linked to health have identified the need to implement measures to ensure the operationalization of the concept of decent work (WHO, 2020; BONIOL et al., 2019), a central goal of the International Labor Organization (ILO, 1998; ILO, 1999). The organization has defined decent work as that which brings together human dignity, equal opportunities, extension of social protection, and sustainable economic growth, as described in the Declaration on the Fundamental Principles and Rights at Work, principles that call for an end to forced labor, the abolition of child labor, and discrimination in the workplace, as well as freedom of association and collective bargaining. In general terms, it is interpreted that the ILO declarations intervene against the most demeaning forms of work activity around the planet, especially against the typical pre-capitalist forms, which restricted free salary labor and the stratification of work by traditional forms.

Contemporary work relations are marked by informalization, which is a concern of the ILO, because it is a significant problem in many countries, among them Brazil. However, the main shared theme on the conception of decent work and international studies of the Nursing workforce and health occupations refers to violence against health workers, among them community health workers who, in different countries, are often at risk of violence and harassment (ILO, 2017). The International Committee of the Red Cross (ICRC) reported 655 violent incidents in healthcare settings between 2008 and 2010 in 16 countries (BUCHAN; DHILLON; CAMPBELL, 2017). In Brazil, $70 \%$ of the nurses and $71.3 \%$ of the nursing technicians feel unprotected against violence at work; $18.8 \%$ of the technicians and $23.9 \%$ of the nurses reported having already suffered some type of violence at work (MACHADO, 2017). 
In addition to violence, there are other wear-out factors that have repercussions on the health of these workers. The relational component of care involves Nursing workers both physically and mentally, so that it strongly impacts on their social and family life. Internationally, healthcare workers have addressed the consequences of job wear out associated with high workloads (BONIOL et al., 2019); among the various problems described are diminished ability to manage workloads and chronic stress, which are causes of dissatisfaction, burnout, musculoskeletal disorders, changes in the sleep pattern due to shift work, emotional and mental fatigue, depression, and absenteeism at work (BUCHAN; DHILLON; CAMPBELL, 2017). The results of a study conducted with Mexican nurses identified an important expression of discontent, when they do not participate in the formulation of policies or organizational decisions that affect work, interfering with the work environment (SQUIRES; FLETCHER; HIDALGO, 2018).

It is worth pointing out that the ILO's description of decent work is incipient when it comes to the problems resulting from contemporary forms of work organization, especially those that affect Nursing workers, who experience the combination of the fundamental characteristics of the work in care with work intensification and overload in the contemporary services. The results of the WHO's Nursing workforce survey showed that the demand requirements of the patients subjected workers to long and irregular working hours (WHO, 2020).

In peripheral capitalist countries, such as Brazil, these wear-out situations are compounded by the daily confrontation with precarious working and living conditions of families that use the health services, especially in primary care and family health units (LACAZ; GOULART; JUNQUEIRA, 2017; SANTOS; SOARES; CAMPOS, 2007), conditions that can lead service users to harsh attitudes toward the closest workers, such as Nursing professionals. In addition to this this wear out, the pressure for performance at work and for meeting goals can also be close to situations of harassment at work; in the Brazilian survey, $64.2 \%$ of the nursing assistants and $71.7 \%$ of the nurses answered affirmatively to the presence of wear-out situations in their professional routines.

Possible consequences related to wear out are the number of weekly hours worked and, consequently, the workload; $40.8 \%$ of the professionals work more than 40 hours a week in the public sector, while in the private sector the percentage 
is $38.5 \%$. It should also be noted the existence of dual work contracts in $25 \%$ of the professionals (MACHADO, 2017).

This situation can be associated with the number of medical leaves, which leads to work absenteeism among the Nursing workers in Brazil. In the period of 1 year the absenteeism of nursing assistants and technicians was $22.6 \%$ among public sector nurses; in the private sector, it was $17.4 \%$ among nursing assistants and technicians and $16.8 \%$ among nurses (MACHADO, 2017). These data may underestimate the real percentage, since there are workers who do not report illness or discomfort, avoiding absence for medical leave, even if they are ill and have limitations to work (UMANN; GUIDO; GRAZZIANO, 2012). In primary care, in the Brazilian reality, workers avoid absences to avoid losing the bonus attributed to teams that reach productivity targets, induced by the National Program for Improving Access and Quality of Primary Care (Programa Nacional de Melhoria de Acesso e da Qualidade da Atenção Básica, PMAQ-AB), ignoring signs and symptoms of diseases (LEIVA, 2019). This phenomenon is known as presenteeism, a condition in which the workers are not absent, even though they present workrelated physical and mental problems. Presenteeism, a consequence of the feeling of job insecurity and excess work, comes from productive restructuring, which practices high rates of unemployment, precarious contracts, and reduction of labor benefits (FLORES-SANDI, 2006).

\section{Final considerations}

The correlation of the institutionalization of Nursing to the historical process of proletarianization is fundamental to understand the contemporary trends of the Nursing workforce in the world, especially because the pillars of proletarianization remain in the expansive development of capitalism, revealing themselves in the particularities, depending on the intersections of gender, racial-ethnic and nationalities, among other manifestations.

The international historical trends are delineated from the working and living conditions of millions of workers in the health services, nuanced by the particularities of national and regional realities. Such an analysis is indispensable, especially since the WHO defined 2020 as the International Year of the Nursing and Obstetric Professionals. 
Both in the world and in Brazil, the Nursing categories represent the most numerous contingent among the health workers, and the Brazilian Nursing workforce follows the main international trends.

The main international trend, both yesterday and today, is the feminization of Nursing, associated with the inequalities of the gender division of work, expressed in the multiple workdays, resulting from the delegation of housework and care for loved ones.

The second trend concerns the salary inequalities, including the range of earnings and labor market positions of women. Inequalities are manifested beyond gender; they are materialized among the health occupations in which Nursing is inserted, and in the dissonances of the labor market supply across countries and regions.

The third international trend is the unequal and combined dynamics of disparities across countries and regions, with the incorporation of the immigrant workforce in the central capitalist countries, with worse working conditions than those of professionals from those countries. In the Brazilian case, regional inequality, as well as the incorporation of sectors of relative overpopulation in the Nursing workforce is also observed, similarly to the relationship with the immigrants in the central capitalist countries.

The fourth international trend refers to the need for better working conditions, in order to face the general manifestation of the wear-out situations of work overload and intensification and their repercussions on the health of the professionals, reported in national and international studies.

Finally, the magnitude of the international trends in the configuration of the Nursing workforce, embedded in heterogeneous health services around the world, renews and complexifies the foundations of capitalist work relations and the realization of specific forms of exploitation among individuals. Both in the world and in Brazil, the social rights of workers, and especially of working women, ultimately depend on structural changes. ${ }^{2}$

\section{References}

AROUCA, A. S. O dilema preventivista: contribuição para a compreensão e crítica da medicina preventiva. Rio de Janeiro: Editora Fiocruz/Unesp, 2003. 268p.

BARBOSA, R. H. S. A “teoria da práxis": retomando o referencial marxista para o enfrentamento do capitalismo no campo da saúde. Trab. educ. saúde, Rio de Janeiro, v. 8, n. 1, p. 9-26, jun. 2010. Disponível em: https://doi.org/10.1590/S1981-77462010000100002 Acesso em: 23 set. 2020. 
BENSAÏD, D. Marx, o intempestivo: grandezas e misérias de uma aventura crítica. Rio de Janeiro: Civilização Brasileira, 1997. 507p.

BONIOL, M. et al. Gender equity in the health workforce: analysis of 104 countries. Health Workforce Working Paper 1. Geneva: World Health Organization, March 2019. 8p. Disponível em: <https://www.who.int/hrh/resources/gender_equity-health_workforce_analysis/en/> Acesso em: 1 maio 2019.

BUCHAN, J.; DHILLON, I. S.; CAMPBELL, J. (Eds.). Health employment and economic growth: an evidence base. Geneva: World Health Organization; 2017. 455p. Disponível em: https:// www.who.int/hrh/resources/WHO-HLC-Report_web.pdf?ua=1> Acesso em: 1 maio 2019.

BUCHAN, J. International Recruitment of Nurses: Policy and Practice in the United Kingdom. Health Serv Res. v. 42, n. 3, p. 1321-35, 2007.

BURAWOY, M. A transformação dos regimes fabris no capitalismo avançado. Revista Brasileira de Ciências Sociais. Rio de Janeiro, v. 5, n. 13, jun. 1990. Disponível em: <http://www.anpocs. com/images/stories/RBCS/13/rbcs13_02.pdf>. Acesso em: 1 mar. 2019.

CRAVEIRO, I. M. R. et al. Desigualdades sociais, políticas de saúde e formação de médicos, enfermeiros e dentistas no Brasil e em Portugal. Ciênc. saúde coletiva, Rio de Janeiro, v. 20, n. 10, p. 2985-2998, out. 2015. Disponível em: <http://www.scielo.br/scielo.php?script=sci_ arttext\&pid=S1413-81232015001002985\&lng=en\&nrm=iso >. Acesso em: 22 set. 2020.

DAL POZ, M. R.; VARELLA, T. C.; SANTOS, M. R. Formação em Saúde: problemas e tendências. In: FUNDAÇÃO OSWADO CRUZ. Projeto Saúde Amanhã. Rio de Janeiro: Fundação Oswaldo Cruz, 2015. 10p. (Textos para discussão, 3). Disponível em: <https:// saudeamanha.fiocruz.br/wp-content/uploads/2016/07/3-PJSSaudeAmanha_Texto0003_ A4_07-07-2015_correcaoFicha-4.pdf>. Acesso em: 20 set. 2020.

DONNANGELO, M. C.; PEREIRA, L. Saúde e Sociedade. São Paulo: Livraria Duas Cidades, 1976. 507p.

ENGELS, F. A situação da classe trabalhadora na Inglaterra. São Paulo: Boitempo, 2008. 388p.

FLORES-SANDI, G. "Presentismo": Potencialidad en accidentes de salud. Acta Méd Costaric., v. 48, n. 1, p. 30-34, 2006.

FOUCAULT, M. Microfísica do poder. Rio de Janeiro: Graal, 2002. 293p.

FREIDSON, E. Profissão médica. Um estudo de sociologia do conhecimento aplicado. São Paulo: Editora Unesp, 2009. 456p.

GADREY, J. Emprego, produtividade e avaliação do desempenho dos serviços. In: SALERNO, M. (Org.). Relação de serviço: produção e avaliação. São Paulo: Editora SENAC, 2001. p. 23-65. GENTIL, D. L. A politica fiscal e a falsa crise da seguridade social: uma história de desconstrução e de saques. Rio de Janeiro: Mauad X, 2019. v. 1. 218p 
GUIMARÃES, N. A.; HIRATA, H. La frontera entre el empleo doméstico y el trabajo profesional de cuidados en Brasil: pistas y correlatos en el proceso de mercantilización. Sociología del Trabajo. Madrid, n. 86, p. 7-27, 2016.

HIRATA, H.; KERGOAT, D. Divisão sexual do trabalho profissional e doméstico: Brasil, França, Japão. In: COSTA, A. O. et al. (Orgs.). Mercado de trabalho e gênero: comparaçóes internacionais. Rio de Janeiro: Editora FGV. 2008. p. 263-278.

HIRATA, H.; KERGOAT, D. Novas configurações da divisão sexual do trabalho. Cadernos de Pesquisa, São Paulo, v. 37, n. 132, dez. 2007, p. 595-609.

HONGYAN, L.; WENBO, N.; JUNXIN, L. The benefits and caveats of international nurse migration. International Journal of Nursing Sciences, v. 1, n. 3, p. 314-317, 2014. Disponível em: <http://www.sciencedirect.com/science/article/pii/S2352013214000787>. Acesso em: 15 jan. 2020.

INTERNATIONAL LABOUR OFFICE. Sectoral Policies Department. Improving employment and working conditions in health services: report for discussion at the tripartite meeting on improving employment and working conditions in health services. Geneva: ILO, 2017. Disponível em: <https://www.ilo.org/sector/activities/sectoral-meetings/WCMS_548288/lang-en/index.htm>. Acesso em: 16 mar. 2019.

JOHNSTON, M. P. Secondary Data Analysis: A Method of which the Time Has Come. Qualitative and Quantitative Methods in Libraries, v. 3, n. 3, p. 8, 2017. Disponível em: <http:// www.qqml-journal.net/index.php/qqml/article/view/169>. Acesso: 21 maio 2019.

LACAZ, F. A.; GOULART, P.; JUNQUEIRA, V. (Orgs.). Trabalhar no SUS: gestão, repercussóes psicossociais e política de proteção à saúde. São Paulo: Editora Hucitec/FAPESP, 2017. 379p.

LEIVA, P. R. L. V. O Programa Nacional de Melhoria de Acesso e da Qualidade da Atenção Básica (PMAQ-AB): gestão do trabalho e repercussóes na saúde dos servidores de um município da região metropolitana de São Paulo - SP. Tese (Doutorado) - Universidade Federal de São Paulo. Escola Paulista de Medicina. São Paulo, 2019.174p. Disponível em: <https://repositorio.unifesp. br/handle/11600/5339>6.

MACHADO, M. H (Coord.). Perfil da enfermagem no Brasil: relatório final: Brasil. Rio de Janeiro: NERHUS-DAPS-ENSP/Fiocruz, 2017. 748p. Disponível em: <http://www.cofen.gov. br/perfilenfermagem/pdfs/relatoriofinal.pdf>

MARX, K. O Capital. Crítica da Economia Política. São Paulo: Boitempo Editorial, Livro I, 2013. 894p.

MELO, C. M. Divisão social do trabalho e enfermagem. São Paulo: Cortez, 1986. 94 p.

MENDES-GONÇALVES, R. B. Trabalho em saúde e pesquisa: reflexão a propósito das possibilidades e limites da prática de enfermagem. In: AYRES, J. R. C. M.; SANTOS, L. (Orgs.). Saúde, sociedade e história. Porto Alegre: Hucitec, 2017. p. 257-281. 
NOGUEIRA, R.P. A força de trabalho em saúde. Revista de administração pública. Rio de Janeiro, v. 17, n. 3, p. 61-70, jul-set. 1983.

ORGANIZAÇÃO INTERNACIONAL DO TRABALHO. Conferencia internacional del trabajo 87, 1999, Ginebra. Trabajo decente. Ginebra: OIT, 1999. 92p. Disponível em: <http:// www.ilo.org/public/spanish/standards/relm/ilc/ilc87/rep-i.htm>. Acesso em: 16 abr. 2020.

ORGANIZAÇÃO INTERNACIONAL DO TRABALHO. Declaração da OIT sobre os Princípios e Direitos Fundamentais no trabalho, 1998, 15p. Disponível em: <www.oitbrasil.org. br>. Acesso em:16 abr. 2020.

ORNELLAS, C. P. Os hospitais: lugar de doentes e de outros personagens menos referenciados. Rev. bras. enferm., v. 51, n. 2, p. 253-262, jun 1998.

RODRIGUEZ, G.; ANGELICA-MUNOZ, L.; HOGA, L. A. K. Cultural experiences of immigrant nurses at two hospitals in Chile. Revista Latino-Americana de Enfermagem, Ribeirão Preto, v. 22, n. 2, p. 187-196, abr 2014. Disponível em: <http://www.scielo. br/scielo.php?script=sci_arttext \&pid=S0104-11692014000200187\&lng=en\&nrm=iso $>$. Acesso em: 28 maio 2020.

SAFFIOTI, H. O trabalho da mulher no Brasil. Revista Perspectivas, São Paulo, v. 5, p. 115-135, 1982.

SANTOS, V. C.; SOARES, C. B; CAMPOS, C. M. S. A relação trabalho-saúde de enfermeiros do PSF no município de São Paulo. Revista da Escola de Enfermagem da USP, v. 41, n. esp., p. 777-81, 2007.

SCHILGEN, B. et al. Health situation of migrant and minority nurses: a systematic review. PLoS ONE.;12:e0179183. 2017

SILVA, K.L et al. Enfermeiros migrantes no Brasil: características demográficas, fluxos migratórios e relação com o processo de formação. Rev. Latino-Am. Enfermagem, Ribeirão Preto, v. 24, e2686, 2016. Disponível em: <http://www.scielo.br/scielo.php?script=sci_ arttext\&pid=S0104-11692016000100308\&lng=en\&nrm=iso

SOUZA, D. O.; MENDONÇA, H. P. F. Trabalho, ser social e cuidado em saúde: abordagem a partir de Marx e Lukács. Interface (Botucatu), v. 21, n. 62, p. 543-552, set. 2017.

SOUZA, H. S.; MENDES, Á. N; CHAVES, A. R. Trabalhadores da enfermagem conquista da formalização, "dureza" do trabalho e dilemas da ação coletiva. Rev. Ciênc. Saúde coletiva, Rio de Janeiro, v. 25, n. 1, p. 113-122, jan. 2020. https://doi.org/10.1590/1413-81232020251.29172019. SQUIRES, A. et al. Un estudio piloto del clima laboral de las enfermeras mexicanas. Hispanic Health Care Int., v. 16, n. 3, p. 145-157, 2018.

TEIXEIRA, E. et al. Panorama dos cursos de graduação em enfermagem no Brasil na década das diretrizes curriculares nacionais. Revista Brasileira de Enfermagem, v. 66, n. esp, p. 102-10, 2013. 
TIJDENS, K. G.; VRIES, D. H. Health workforce remuneration: Comparing wage levels, ranking and dispersion of 16 occupational groups in 20 countries. University of Amsterdam, AIAS Working Paper. Amsterdam, 2011. p. 11-111.

UMANN, J.; GUIDO, L.; GRAZZIANO, E. S. Presenteísmo em enfermeiros hospitalares. Revista. Latino-Americana de Enfermagem, v. 20, n. 1, p. 8, 2012. Disponível em: <http://www. scielo.br/pdf/rlae/v20n1/pt_21.pdf>. Acesso em: 21 abr. 2019.

WORLD HEALTH ORGANIZATION. Global spending on health: a world in transition. Geneva: WHO, 2019. Disponível em: <https://www.who.int/health_financing/documents/ health-expenditure-report-2019/en/> Acesso em: 3 abr. 2020.

. State of the world's nursing 2020: investing in education, jobs and leadership.

2020. Disponível em: <https://www.who.int/publications/i/item/nursing-report2020\#: : :text=The\%20State $\% 20$ of $\% 20$ the $\% 20$ world's,education $\% 2 \mathrm{C} \% 20$ jobs $\% 2 \mathrm{C} \% 20$ and\%20leadership>. Acesso em: 3 abr. 2020.

\section{Notes}

${ }^{1}$ By pointing out that there may be professionals enrolled in more than one category, the Federal Nursing Council discloses a table in 2020 of more than 2 million and 300,000 professionals registered in http:// www.cofen.gov.br/enfermagem-em-numeros

${ }^{2}$ H. S. de Souza, C. A. Trapé, C. M. S. Campos and C. B. Soares equally participated in the conception and design of the research, data collection, data analysis and interpretation, writing and critical review of the manuscript. 


\section{Resumo}

A força de trabalho de enfermagem brasileira frente às tendências internacionais: uma análise no Ano Internacional da Enfermagem $\mathrm{O}$ artigo analisa a condição da força de trabalho da enfermagem brasileira frente às tendências internacionais. Os diagnósticos de publicaçóes de organizaçóes internacionais balizaram a confrontação das tendências internacionais com a realidade da enfermagem brasileira, a partir de dados secundários de pesquisa. A análise permite afirmar que a força de trabalho da enfermagem brasileira segue as tendências internacionais, essencialmente, porque a divisão social e sexual do trabalho, alicerce da origem da enfermagem como ocupação capitalista, se mantém. Contemporaneamente, o pressuposto históricoestrutural da proletarização feminina fundamenta: as disparidades salariais e de acesso a posições destacadas no mercado entre homens e mulheres; desigualdades combinadas entre naçóes e regióes na oferta do mercado de trabalho, o que estimula a imigração de profissionais; o aumento da exploração dos profissionais mais velhos, no contexto de restrição de acesso aos direitos de aposentadoria e trabalhistas; e a exposição à violência e ao assédio, associada ao potencial de desgaste da sobrecarga e intensificação do trabalho, que trazem como consequência o adoecimento dos trabalhadores. Em síntese, observa-se que os pilares da proletarização feminina e da profissionalização da enfermagem permanecem nas formas diferenciadas de exploração da força de trabalho atuais, sendo configuradas a depender das interseçóes de gênero, étnico-raciais e regionalidades-nacionalidades.

> Palavras-chave: condições de trabalho; enfermagem; força de trabalho; mulheres trabalhadoras; serviços de saúde. 